chemistry. Favorable responses were made and twenty different committees appointed. There were from America two (American Chemical Society and American Academy of Arts and Sciences) ; Belgium, two ; Germany, five; England, one ; Holland, one ; Japan, one ; Italy, one ; Austro-Hungary, four; Russia,one; Sweden, one; Switzerland, one. Denmark, France and Norway alone made no response to the overtures. Altogether there were fifty-six members of the international committee.

On December 15, 1899, a circular was addressed to these members asking for opinions upon three points :

1. Shall $\mathrm{O}=16$ be adopted as the standard of atomic weights?

2. To how many decimal places shall the atomic weights be given?

3. Is a smaller permanent committee on atomic weights desirable?

Forty-nine replies were received. As regards the standard, forty favored $\mathrm{O}=16$, seven $\mathrm{H}=1$, while Cannizzaro desired both, and Fresenius preferring $\mathrm{O}=16$ would be satisfied with either. It is interesting to note that six of the votes for $\mathrm{H}=1$ were German, six other Germans voting for $\mathrm{O}=16$. The only other vote for $\mathrm{H}=1$ was from Professor Mallet. Of the other Americans Richards, Gibbs, Remsen and Smith, voted for $\mathrm{O}=16$, while Clarke and Morley made no reply.

On the second point opinions differed so widely, that the committee was constrained to leave the decision to the smaller permanent international committee to be later appointed. Of the Americans, Richards, Gibbs and Remsen favor stating one figure which is uncertain by more than a unit, while Smith and Mallet would give only so many decimals that the last figure should be correct to less than half a unit.

Views were practically unanimous in favor of a small permanent committee and the committee recommended the appoint- ment of a permanent committee of three chemists who have given special attention to the subject of atomic weights.

In conclusion the committee express a desire to receive the opinions of chemists outside of the international committee as to their preferences for the standard. Such replies should be sent before November 15th, to Professor Landolt, Berlin, N. W. Bunsenstrasse, 1.

In this connection it is interesting to note that the work of this committee is the final outcome of an agitation which was be. gun in this country in 1889 by Dr. F. P. Venable in a paper published in the Journal of Analytical Chemistry (3:48), and which was taken up the following year by Dr. Brauner, of Prague, and very warmly discussed before the German Chemical Society by Ostwald, V. Meyer, Seubert and Brauner. At that time Meyer and Seubert advocated $\mathrm{H}=1$ for the standard and this view has had many supporters in Germany but few elsewhere. The argument in its favor seems to be the impossibility from a didactic standpoint of taking sixteen as a unit. In his first paper Venable pointed out clearly the distinction between the idea of standard and unit, showing that a standard need not be a unit, and this view has been generally adopted by most chemists outside of Germany.

J. L. H.

\section{THE FOSSIL SHELLS OF THE LOS ANGELES TUNNEL CLAYS.}

THe detection of a species of Radiolites, by Mr. Homer Hamlin, in the clays perforated in the course of drifting the Third Street tunnel in the city of Los Angeles is a discovery of noteworthy importance by reason of its bearing upon the question of the geologic age of the region hereabout. These clays, which will be more fully described by Mr. Hamlin or myself when the tunnel excavation is completed, have 
yielded other interesting forms-many examples of a new species of Lima (L. Hamlini Dall) of unusual size and of quite distinct characteristics, as well as two of the three species of 'Plagiostoma,' described and figured by the late Dr. John B. Trask in the Proc. California Acad. Sciences in 1856. They were assigned by him to 'the Cretaceous rocks of Los Angeles' County. These are listed (? as one and the same species) under the head of 'Tertiary and Quaternary Mollusca,' in Dr. J. G. Cooper's 'Catalogue of Californian Fossils,' $*$ as Pecten Pedroanus Trask, Mioc.- 'San Pedro,' with the remark, 'may be an Aucella and Cretaceouis.'

Dall $\dagger$ refers to Trask's species ' $P$. Pedroanus $+P$. annulatus' and ' $P$. truncata' in his comments on the Pectens of the West Coast in the 'Tertiary Fauna of Florida,' qualifiedly referring them to the Miocene. Dr. Cooper in his prefatory remarks to the Catalogue above quoted, says, "It must be remarked that the exact geological position of many fossils in the Tertiary and Cretaceous strata is still unsettled, there not being such distinct divisions between them in California as in some other countries."

The Hippuritidæ which Woodward placed in his Section B, Family VIII. of the Conchifera, includes the genera, Hippurites and Radiolites of Lamarck as well as other more or less closely related groups, in the Order Rudistes of Lamarck. As these forms are but little known, it may be well to quote Woodward's description of Radiolites, which is based on examples from the chalk beds of Europe, of which he has given figures in his Manual :\$ "Shell inversely conical, biconic, or cylindrical; valves dissimilar in structure; internal margins smooth or finely striated,

* Seventh Ann. Rep. State Mineralogist of Cal., 1887-88, pp. 221-308.

† Trans. Wagner Free Inst. Part IV., Vol. III., p. 705, April, 1898.

$\ddagger$ Recent and Fossil Shells. Ed., 1880, pp. 446-7. simple, continuous; ligamental inflection very narrow, dividing the deep and rugose cartilage pits; lower valve with a thick outer layer often foliaceous; its cavity deep and straight, with two dental sockets and lateral muscular impressions; upper valve, flat or conical with a central umbo ; outer layer thin radiated; umbonal cavity inclined towards the ligament; teeth angular, striated, supporting curved and subequal muscular processes."

The examples from the tunnel clays consist of the remains of four individuals, being portions of the lower valves of two, and the nearly perfect upper valve of a third. The fourth, also an upper valve, is in still better condition; all are bedded in the clay, but are too fragile to admit of separation from the matrix. The upper valve is discoidal in shape and moderately convex, the umbo central ; the surface in the third example somewhat rugose, and exhibiting concentric growth-ridges and radiating sculpture; its diameter is about $47 \mathrm{~mm}$., or an inch and three quarters. In the fourth (upper valve) the concentric sculpture is absent and the radiating feature more conspicuous; this consists of closely set thread-like ridges, which extend from the umbo to the extreme periphery of the valve, projecting somewhat beyond, forming a pectinated edge or margin, as seen in certain finely sculptured Limpets and Siphonarias. The diameter of this last is slightly in excess of the other, being $49 \mathrm{~mm}$. These upper valves were found at points so distant from the lower valves, as to warrant the conclusion that they were never connected, but are parts of separate individuals.

But little is left of the lower valves; their concavity is shown by the casts in the clay. Portions of the curious foliaceous lamellæ remain intact, so that their character and relation to the outer surface of said valve is indicated.

The umbos are central or nearly so, in 
both upper and under valves, and the concavity of the latter is about twice as great as the convexity of the upper valve.

Perhaps a better idea of the form and other features of the lower valve may be understood by the following: Take an elevated limpet-shell that is circular, or nearly so in marginal outline with an apex that is central. Cover the outside with closely-set radiating lamellæ much elevated or produced, standing up at a right angle from the surface of the shell; the lamellæ as thin as writing paper and projecting beyond the extreme margin or periphery. Now reverse this limpet-shell so that the concavity will be uppermost, and press it firmly into a rather compact clayey sea-bed and the general aspect of the lower valve of the Radiolite we are considering, when in situ will be seen, and the function of these external lamellæ suggested. Whether the lamellæ, which are so closely set that the interspaces are about as narrow as the lamellæ are thin, are of calcareous or chitinous matter is a point for discussion. The texture of their surfaces, character of fracture, slight prismatic reflections and the fact that they are apparently less perishable than the other portions, favor the latter or chitinous character.

There are no indications tending to show that the lamellæ were inclosed by an exterior wall, which would make them septæ or partitions, and the inter-spaces cells. The lamellar as well as the other exposed parts are much discolored by ferro-oxide making it difficult to determine, so far as color is involved, whether the lamellæ are of a calcareous or ligamentary substance, though the latter is suggested.

"The foliations of the lower valve," of $R$. fleuriausus, according to Woodward, "are sometimes as thin as paper and several inches wide."

In the remains from the tunnel these are about five-eighths of an inch in width.
In the related Chamada we find the various species fix their shells (lower valves), by means of a limey deposit, the same as the substance of their shells, to hard surfaces, cobble-stones, boulders, fixed rock, coral-fronds and to the surfaces of other shells. The grain, texture and lack of density in the ordinary clays are not favorable to attachment by a flat or horizontal calcareous deposit. The remarkable lamellar development in the Radiolites whether epidermidal or calcareous, meets this character of sea-bed, by the projection of the lamellæ into the clay, and furnishes an interesting illustration of special adaptation to peculiarities of habitat or station, for by these lamellæ which cover the entire surface (presumably) of the under valve, fixity is obtained in an effective manner.

These forms probably lived where patches of the sea-bed of a clayey character prevailed, at a depth below the agitation of the water during storms.

For a more thorough determination of the characters of this Radiolite, which for convenience may be called $R$. Hamlini, further material is awaited. While the conditions of the specimens thus far obtained does not admit of a complete diagnosis, they are nevertheless sufficient to indicate the generic relations. These tunnel fossils point to relationship between the clays in which they occur, and the Walalla,* Mendocino county beds visited by Dr. G. F. Becker. The Walalla beds were found to contain fragments of the rare Coralliochama Orcutti White, previously discovered by Mr. C. R. Orcutt at Todos Santos Bay, Lower California. C. Orcutti occurs at La Jolla, San Diego county, where specimens were collected some years ago by Mr. Hamlin.

Dr. Becker's Walalla collection included other species as well as Coralliochama, and

* Walalla is the Indian name: Gualalla, the U. S. Postoffice title. 
these, in connection with the Orcutt and La Jolla localities, to quote the comments of Dr. White,* 'seem to represent the fauna of a cretaceous formation, which has not heretofore been recognized,' though Dr. Trask's assignment of his species of 'Plagiostoma' to the Cretaceous should be borne in mind.

Examples of Radiolites Hamlini have also been met with in the Broadway tunnel excavation. These tunnels which are several blocks apart, run in different directions; that on the line of Third street being an east-and-west tunnel, while the Broadway, follows a northerly and southerly course; both penetrate the high ridge overlooking the city, known as Fort Hill, the site of the earthworks thrown up by Fremont at the time of the 'conquest' of Southern California.

The clays excavated on Shatto Heights in the preparation of a site for the Shatto mansion on Orange street are perhaps of a later age than those of the tunnels. The Shatto clays contained shells and sharks' teeth; the former were not saved by $\mathrm{Mr}$. Shatto, and were covered up by the graders just before my visit in 1887 .

Rob't E. C. Stearns.

Los Angeles, June 12, 1900.

\section{THE ROYAL COLLEGE OF SURGEONS.†}

THIs year marks the completion of a century since the Royal College of Surgeons received its Royal charter of incorporation from George III.; and the centenary of that event, which, to be precise, happened March 22, 1800, has just been celebrated. But, though the present corporation can only claim a lifetime of 100 years, it can count its descent in a direct line back to a much more remote antiquity, for a Guild of Surgeons, whether technically incorpor-

* Vide Bulletins 15 and 18, U. S. Geological Survey.

$\dagger$ From the London Times. ated or not, seems to have been in existence in London more than six centuries ago, and to have existed ever since in one form or another. In 1368 mention occurs of the surgeons as a distinct body ; and the license without which they could not, apparently, practice in the City of London enjoins upon them, among other things, that they serve the people well and truly in their cures and only charge reasonable fees. The association of barbers and surgeons also dates from the same early times, and seems to have been a result of ecclesiastical influence. It would naturally be supposed that the Church would be the repository of the surgical knowledge of the day, just as it was of other science and art, and such indeed appears to have been the case until Innocent III. forbade priests to perform surgical operations, on the ground that the Church ' abhoret a sanguine.' But the prohibition was not sufficient to make them give up all attempts to control surgical practice, and when they were shut off from employing direct methods they had recourse to indirect ones. They began to 'push' the barbers-a class of men of whose services they had, of course, constant need, and who were in the habit of performing minor surgical operations-and gradually erected them into a fellowship of barber-surgeons, a Barbers' Guild being referred to as early as 1308 in the records of the City of London. As may easily be imagined, the cry of unqualified practitioners soon made itself heard, and various regulations were asked for to prevent unskilful persons from practicing the art both by the surgeons and by the better sort of barber-surgeons, who evidently became differentiated from the others who were barbers pure and simple.

Among the most important events in the history of this Guild of Surgeons were its combination with the physicians and the incorporation, about 1423 , of the two into one distinct body to control all persons en- 